\title{
Immunogenicity of the carcinoembryonic antigen derived peptide 694 in HLA-A2 healthy donors and colorectal carcinoma patients
}

\author{
Pedro M. S. Alves · Sebastien Viatte · Theres Fagerberg • Olivier Michielin · Gabriel Bricard • \\ Hanifa Bouzourene · Henri Vuilleumier · Thorsten Kruger · Jean-Claude Givel · Frédéric Lévy · \\ Daniel E. Speiser $\cdot$ Jean-Charles Cerottini $\cdot$ Pedro Romero
}

Received: 29 January 2007 / Accepted: 23 March 2007 / Published online: 20 April 2007

(C) Springer-Verlag 2007

\begin{abstract}
Carcinoembryonic antigen (CEACAM5) is commonly overexpressed in human colon cancer. Several antigenic peptides recognized by cytolytic CD8+ T-cells have been identified and used in colon cancer phase-I vaccination clinical trials. The HLA-A*0201-binding $\mathrm{CEA}_{694-702}$ peptide was recently isolated from acid eluted MHC-I associated peptides from a human colon tumor cell line. However, the immunogenicity of this peptide in humans
\end{abstract}

P. M. S. Alves · G. Bricard · D. E. Speiser · P. Romero $(\bowtie)$ Division of Clinical Onco-Immunology,

Ludwig Institute for Cancer Research, Hôpital Orthopédique,

HO-05, Rue Pierre-Decker, 4, 1005 Lausanne, Switzerland

e-mail: Pedro.romero@isrec.unil.ch

P. M. S. Alves · S. Viatte · T. Fagerberg · O. Michielin · F. Lévy ·

J.-C. Cerottini

Ludwig Institute for Cancer Research, Lausanne Branch,

University of Lausanne, Epalinges, Switzerland

P. M. S. Alves · S. Viatte

Molecular Oncology, National Center for Competence

in Research (NCCR), Lausanne, Switzerland

H. Bouzourene

Institut Universitaire de Pathologie,

Centre Hospitalier Universitaire Vaudois,

Lausanne, Switzerland

H. Vuilleumier · T. Kruger · J.-C. Givel

Department of Surgery,

Centre Hospitalier Universitaire Vaudois,

Lausanne, Switzerland

T. Fagerberg · O. Michielin

Swiss Institute of BioInformatics, Basel, Switzerland

O. Michielin

Multidisciplinary Oncology Center,

Lausanne University Hospital, Lausanne, Switzerland remains unknown. We found that the peptide $\mathrm{CEA}_{694-702}$ binds weakly to HLA-A*0201 molecules and is ineffective at inducing specific CD8+ T-cell responses in healthy donors. Immunogenic-altered peptide ligands with increased affinity for HLA-A*0201 were identified. Importantly, the elicited cytolytic T lymphocyte (CTL) lines and clones cross-reacted with the wild-type $\mathrm{CEA}_{694-702}$ peptide. Tumor cells expressing CEA were recognized in a peptide and HLA-A*0201 restricted fashion, but high-CEA expression levels appear to be required for CTL recognition. Finally, CEA-specific T-cell precursors could be readily expanded by in vitro stimulation of peripheral blood mononuclear cell (PBMC) from colon cancer patients with altered CEA peptide. However, the CEAspecific CD8+ T-cell clones derived from cancer patients revealed low-functional avidity and impaired tumor-cell recognition. Together, using T-cells to demonstrate the processing and presentation of the peptide CEA694-702, we were able to corroborate its presentation by tumor cells. However, the low avidity of the specific CTLs generated from cancer patients as well as the high-antigen expression levels required for CTL recognition pose serious concerns for the use of CEA694-702 in cancer immunotherapy.

Keywords CTL - Tumor immunology - Cancer vaccines . Tetramers

\begin{tabular}{ll}
\multicolumn{2}{l}{ Abbreviations } \\
$\mathrm{h}$ & Hour \\
HLA-A2 & HLA-*0201 \\
mAb & Monoclonal antibody \\
MFI & Mean fluorescence intensity \\
n.d. & Not done \\
PCR & Polymerase chain reaction
\end{tabular}




\section{Introduction}

Carcinoembryonic antigen (CEA), also designated CD66e or CEACAM5, belongs to a heterogeneous protein family that shares common immunoglobulin domains [13]. CEA confers homophilic and heterophilic cell adhesion and may contribute to the metastatic progression of tumors [16]. CEA has also been reported to block cell differentiation and to cooperate with other molecules in cellular transformation $[8,34]$.

The CEA has been proposed as a potential target antigen for immunotherapy because it is overexpressed by most colorectal, gastric, and pancreatic carcinomas, by $50 \%$ of breast cancers, and by $70 \%$ of non-small cell lung carcinomas [5, 38]. In contrast, CEA is expressed at lower levels in normal epithelial cells and fetal tissue [23]. Increased levels of soluble CEA can be detected in the serum from most patients with CEA-positive tumors, which allows the use of CEA as surrogate marker for disease progression and response to therapy $[12,20]$.

Numerous clinical studies have been performed in the last few decades targeting CEA for immunotherapy of colorectal carcinoma. CEA-derived antigens were delivered as recombinant vectors, peptides, or full-length protein (for review see [5, 6]). Overall, variable proportions of patients had positive DTH responses upon vaccination, and although the majority of vaccinated patients have been shown to mount CEA-specific T-cell and antibody responses, clinical results have been disappointing. Moreover, only rarely the CEA-specific cytolytic T lymphocyte (CTL) responses correlated with decreased CEA serum levels or clinical responses. Of note, one study testing immunization with autologous Flt3L-induced dissociation complex (DCs) pulsed with the HLA-A*0201-restricted peptide CEA-CAP1-6D, an analog of CEA $_{605-613}$ peptide (YLSGANLNL), reported two complete clinical responses out of 12 metastatic colorectal cancer patients [10].

A novel HLA-A*0201-restricted peptide was recently identified in eluted peptides from MHC class-I molecules of a human colon cancer cell line (SW1116) and fresh human colon cancer tissue [33]. From a list of CEA-derived peptides predicted to be potential binders of HLA-A*0201, the authors could only identify one new single peptide derived from CEA, which was the peptide $\mathrm{CEA}_{694-702}$ (GVLVGVALI). Interestingly, both the cell line and the fresh tumor tissue presented the same peptide. This biochemical approach is independent of the preexistence of tumor-specific CD8+ T-cells, commonly used for the identification of novel processed and presented HLA-restricted epitopes [3]. Although the authors demonstrated the processing and presentation of the $\mathrm{CEA}_{694-702}$ peptide, no immunogenicity data have been reported [33].
In this manuscript, we evaluated the antigenicity and immunogenicity of the $\mathrm{CEA}_{694-702}$ peptide. We found that the native $\mathrm{CEA}_{694-702}$ peptide is poorly immunogenic in healthy donors. In addition, this peptide binds weakly to the HLA-*0201 (HLA-A2) molecule. In contrast, analogs with improved binding to HLA-A*0201 molecules were immunogenic. CD8+ T-cell clones cross-reactive with analog and native peptides were of low to intermediate avidity. Moreover, these clones recognized tumor cells with high-CEACAM5 expression, confirming that $\mathrm{CEA}_{694-702}$ peptide is processed by human tumor cell lines and recognized under certain circumstances. Finally, we found that $\mathrm{CEA}_{694-702}$-specific $\mathrm{T}$-cell responses can be induced in peripheral blood mononuclear cell (PBMC) in colon cancer patients. However, in contrast to healthy donor-derived $\mathrm{CTL}, \mathrm{CD}^{+}{ }^{+} \mathrm{T}$-cell clones generated from cancer patients had lower avidity and were unable to recognize CEAexpressing tumor cells.

\section{Materials and methods}

\section{Synthesis of peptides}

Peptides described in Table 2 as well as $\mathrm{HIVpol}_{589-597}$ (IVGAETFYV), FluMA ${ }_{58-66}$ (GILGFVFTL), and NYESO-1 ${ }_{157-165}$ (SLLMWITQA) were synthesized in an automated peptide synthesizer 432A (Applied Biosystems, Weiterstadt, Germany) following the N-(9-fluorenyl)methoxycarbonyl/tert-butanol strategy. Synthesis products were analyzed by HPLC (Varian star; Zinsser, Munich, Germany) and MALDI-TOF mass spectrometry (G2025A; HewlettPackard, Waldbronn, Germany). Peptides were purified by preparative HPLC and dissolved in DMSO to a final concentration of $10 \mathrm{mM}$.

\section{Patients}

Peripheral blood mononuclear cells of HLA-A*0201 colon cancer patients were obtained after informed consent. The study protocol was approved by the Ludwig Institute for Cancer Research protocol review committee, as well as by the medical and ethical committees of the University Hospital (Lausanne, Switzerland). All patients had primary colorectal adenocarcinomas and had not been enrolled in any adjuvant therapy at the time of blood sampling.

Major histocompatibility complex/peptide multimers and monoclonal antibodies

Phycoerythrin-labeled HLA-A2/peptide multimers [1] were synthesized around $\mathrm{CEA}_{694-702}$ peptide and designed peptide analogs. The cut-off value for detection of antigen-specific 
$\mathrm{CD} 8^{+}$T-cells with HLA-A2/peptide multimers was determined by flow cytometry analysis of $\mathrm{CD}^{+} \mathrm{T}$-cells from HLA-A2 ${ }^{+}$and HLA-A2 ${ }^{-}$human healthy donors stained with the multimers. Monoclonal antibodies (mAbs) were from Becton Dickinson, San Jose, CA, USA. Dead cells, in all situations, were electronically excluded by Propidium Iodine staining.

\section{Cell lines}

Human colon cell line SW1116 was the kind gift from H.G. Rammensee (Universitaet Tuebingen, Tuebingen, Germany). Human colon cell lines SW403, SW480, COLO201, SW620, LOVO, HCT-116, T84; gastric cancer cell line KATOIII; and NK-sensitive cell line K562 were bought from ATCC, Molsheim, France. Na8MEL was the kind gift from Francine Jotereau (INSERM, Nantes, France) and Me 290 melanoma cell line was generated from a melanoma patient (LAU 203) by Donata Rimoldi (Ludwig Institute for Cancer Research, Lausanne Branch, Switzerland-[40]). All tumor cell lines were used in CTL assays at exponential phase of cell culture growth and at $\sim 80 \%$ confluence.

Measurement of peptide relative affinity to HLA-A*0201

The protocol used was as previously described [39] and applied elsewhere [2, 3, 9]. Briefly, T2-cells were incubated at $37^{\circ} \mathrm{C}$ for $16 \mathrm{~h}$ with peptides at concentrations ranging from 100 to $0.1 \mu \mathrm{M}$, and then stained with BB7.2 mAb [25] to quantify the surface expression of HLA-A*0201. For each peptide concentration, HLA-A2-specific staining was calculated as the $\%$ of the staining obtained in the presence of $100 \mu \mathrm{M}$ of the reference peptide $\left(\mathrm{HIVpol}_{589-597}\right.$; IVGAETFYV). The RA score is the ratio of the concentration of each peptide to the concentration of the reference peptide that induces $20 \%$ of the HLA-A2 expression; the lower the RA is, the stronger the peptide binds to HLA-A2. The mean RA for each peptide was determined from at least three independent experiments. In all experiments, $20 \%$ of HLA-A2 expression using the reference peptide was obtained at concentrations of $1-3 \mu \mathrm{M}$.

Assessment of peptide/HLA-A*0201 complex stability

As previously described [39], T2-cells were incubated overnight with $100 \mu \mathrm{M}$ of each peptide at $37^{\circ} \mathrm{C}$ in serumfree medium. The cells were then incubated with Brefeldin A (Sigma-Aldrich, St. Louis, MO, USA) at $10 \mu \mathrm{g} / \mathrm{ml}$ for $1 \mathrm{~h}$, washed, incubated at $37^{\circ} \mathrm{C}$ during $0,1,2,4$, or $6 \mathrm{~h}$ in the presence of Brefeldin A $(50 \mathrm{ng} / \mathrm{ml})$ and finally stained with BB7.2 moAb. For each time point, peptide-induced HLA-A2 expression was calculated as: mean fluorescence of peptide-incubated T2-cells-mean fluorescence of T2cells treated in similar conditions in the absence of peptide. DC50 DC was defined as the time required for the loss of $50 \%$ of the HLA-A $* 0201 /$ peptide complexes stabilized at $t=0 \mathrm{~h}$

In vitro expansion of circulating antigen specific $\mathrm{CD} 8^{+} \mathrm{T}$ lymphocytes

Peripheral blood mononuclear cells were isolated by FicollHypaque (Beckman-Coulter, Fullerton, CA, USA) from the blood of human healthy donors. For generation of autologous dendritic (DC) cells, PBMCs were allowed to adhere into Petri-dishes during $2 \mathrm{~h}$ at $37^{\circ} \mathrm{C}$. Adherent cells were incubated with $700 \mathrm{IU} / \mathrm{ml}$ of Granulocyte-Macrophage Colony Stimulating Factor (R\&D Systems, Minneapolis, MN, USA) and 1,000 IU/ml of IL-4 (R\&D Systems) in CTL culture medium [RPMI 1640 (Invitrogen, Basel, Switzerland ), $8 \%$ pooled human serum, Penicilin/Streptavidin (Invitrogen), $50 \mu \mathrm{M} \beta$-mercaptoethanol (Sigma)]. CD8+ T-cells were purified from non-adherent PBMC by negative selection using immunomagnetic beads (Miltenyi, Bergisch Gladbach, Germany) following the manufacturer's instructions. For priming, DC were extensively washed and pulsed at least during $2 \mathrm{~h}$ with $10 \mu \mathrm{M}$ of peptide in serum-free media. Pulsed DCs were later maturated with LPS (Sigma) at $5 \mu \mathrm{g} / \mathrm{ml}$ overnight. Co-culture of DCs with autologous CD8+-purified T-cells was done at 1:5 ratio in CTL culture medium. IL-2 (Proleukin, Roche, Switzerland) at $20 \mathrm{IU} / \mathrm{ml}$ was added at day 2 and the culture medium was renewed every other day. At days 7 and 14, CTLs were restimulated with overnight peptide-pulsed $(10 \mu \mathrm{M})$ T2-cells, which were lethally irradiated. The cultures were evaluated at day 21 for the presence of peptide-specific expanded CD8+ Tcells. In vitro stimulation of PBMC with CEA-derived peptides in microcultures was performed as previously described [21] using freshly isolated PBMCs at $0.2 \times$ $10^{6}$ cells/well (96 U-bottom plate) (FALCON, Franklin Lakes, NJ, USA) in CTL culture medium in the presence of $10 \mu \mathrm{M}$ of peptide. IL-2 was added at day 2 at 1,000 $\mathrm{IU} / \mathrm{ml}$. The medium was changed every other day and the induction of specific $\mathrm{CD}^{+} \mathrm{T}$-cells was evaluated at day 10.

Multimer-guided cell sorting and cloning

The expansion of CEA peptide-specific CD8+ T-cells stimulated by co-culture with autologous DC or in the peptide-stimulated PBMC microcultures was evaluated by multicolor flow cytometry of day 21 or 10 , respectively, employing peptide-MHC multimers. The cultures were harvested and washed in PBS 0.2\% BSA, 50 mM EDTA (Facs buffer). PE-conjugated multimers were incubated at room 
temperature during $1 \mathrm{~h}$ in FACS buffer. After washing, cells were incubated with FITC-conjugated anti-human CD8 $\mathrm{mAb}$ at $4^{\circ} \mathrm{C}$ during $20 \mathrm{~min}$. Cells were immediately acquired in a FACsVantage cell sorter. Multimer ${ }^{+} \mathrm{CD} 8^{+}$ cells were electronically gated and sorted at $4^{\circ} \mathrm{C}$. Sorted cells were promptly placed in culture in CTL culture medium with $150 \mathrm{IU} / \mathrm{ml}$ of rhIL-2 overnight. The next day, sorted cells were cloned by co-culture in limiting dilution conditions $(0.3$ cells/well) in NUNCLON plates (NUNC, Roskilde, Denmark) with $10^{4}$ irradiated allogenic PBMC, $150 \mathrm{IU} / \mathrm{ml}$ of IL-2, and $1 \mu \mathrm{g} / \mathrm{ml}$ of phytohemagglutinin-leukoagglutinin (PHA-L) (REMEL, Dartford, UK). Proliferating wells were screened after 7-9 days of culture and expanded to 96 U-bottom plate wells. Cells were then restimulated with irradiated allogenic PBMCs, IL-2, and PHA$\mathrm{L}$ as above. Cultures were replenished with media and split into new plates as required. CTL clones generated were evaluated with multimers for TCR specificity and later for functional antigen-triggered cytolitic activity.

\section{Chromium release-based cytolytic assay}

Cytolytic activity was assessed using a $4 \mathrm{~h}$ chromium release assay. To evaluate the relative avidity for the antigen ligand of the CTL clones generated upon multimerguided cell sorting, radiolabeled T2-cells were plated in 96 V-bottom plates and pulsed with a range of peptide concentrations $\left(10^{-5}\right.$ to $\left.10^{-14} \mathrm{M}\right)$. Cells were incubated with peptide at least $1 \mathrm{~h}$ before addition of cloned CTL at an effector to target cell ratio of 10:1. In tumor recognition assays, "hot" targets were co-cultured with T-cell clones at different effector to tumor cell ratios. About $50 \mathrm{IU} / \mathrm{ml}$ of IFN- $\gamma$ (R\&D Systems) was added to tumor cells culture medium during $72 \mathrm{~h}$ prior to some tumor recognition assays. $\mathrm{Na}^{51} \mathrm{Cr}$ released in the media was quantified using LumaPlate-96 plates (PerkinElmer, Wellesley, MA, USA) and a TopCount- $\gamma$-counter (PerkinElmer).

Reverse-transcription and semi-quantitative PCR

Total RNA was extracted with RNeasy Mini Kit (Qiagen, Hilden, Germany). About $1 \mu \mathrm{g}$ RNA was then reverse-transcribed to cDNA using M-MLV reverse transcriptase (Invitrogen). The following primers were used for semiquantitative polymerase chain reaction (PCR): $\beta$-actin forward 5'-GGC ATC GTG ATG GAC TCC G-3' reverse 5'-GCT GGA AGG TGG ACA GCG A-3'; CEACAM3 forward 5'-TTG CCA AAA CTG GAA GAA CC-3' reverse 5'-AGC CAC TTC TGC TTT GTG GT-3'; CEACAM4 forward 5'CGC ATA CAG TGG TCG AGA GA-3' reverse 5'-TGG GAC GTT GTT TTG GTG TA-3'; CEACAM5 forward 5'-AAC CCA GAA CCC AGT GAG TG$3^{\prime}$ reverse 5'-ATT GCT GGA AAG TCC CAT TG-3'.
Thermocycling conditions for CEACAM3, CEACAM4, and CEACAM5 were the following: $94^{\circ} \mathrm{C}, 15^{\prime \prime} ; 25 \times\left(94^{\circ} \mathrm{C}\right.$ $\left.15^{\prime \prime}, 60^{\circ} \mathrm{C} 30^{\prime \prime}, 72^{\circ} \mathrm{C} 60^{\prime \prime}\right), 72^{\circ} \mathrm{C} 10^{\prime}, 4^{\circ} \mathrm{C}$ pause. All reactions were performed in a T3 thermocycler (Biometra, Göttingen, Germany). PCR products were visualized by electrophoresis on agarose gel stained with ethidium bromide.

\section{Results}

Peptide $\mathrm{CEA}_{694-702}$ is poorly immunogenic and displays low-binding activity to HLA-A*0201 molecules

Labeling of PBMC samples from five HLA-A2+ healthy donors with $\mathrm{A} 2 / \mathrm{CEA}_{694-702}$ multimers in conjunction with anti-hCD8 antibody did not detect $\mathrm{CEA}_{694-702}$-specific T-cells (not shown). The threshold of detection could be fixed at $0.07 \pm 0.02 \%$ - a value comparable to the values determined for other HLA-A2/peptide multimers used in our laboratory [37]. To probe the potential immunogenicity of peptide $\mathrm{CEA}_{694-702}$, we performed multiple in vitro stimulations of PBMCs from HLA-A*0201 ${ }^{+}$healthy donors and evaluated the presence of expanded peptide-specific $\mathrm{CD} 8^{+}$ T-cells by labeling with $\mathrm{A} 2 / \mathrm{CEA}_{694-702}$ multimers and flow cytometry. As demonstrated in Fig. 1a and summarized in Table 1, the peptide $\mathrm{CEA}_{694-702}$ did not generate detectable peptide-specific responses either after stimulation of PBMC with peptide and IL-2, or after multiple stimulations of purified $\mathrm{CD} 8^{+} \mathrm{T}$-cells with autologous peptide-pulsed dendritic cells.

A major determinant of peptide immunogenicity is its ability to stably bind to the presenting MHC molecule. Therefore, we determined $\mathrm{CEA}_{694-702}$ peptide's affinity and stability to HLA-A*0201 molecules using in silico and in vitro methods. As shown in Table 2, the native $\mathrm{CEA}_{694-702}$ peptide was predicted to have relatively low-affinity scores when compared with a known viral epitope $\left(\mathrm{HIVpol}_{589-597}\right.$, a good binder to HLA-A*0201) [39]. These predictions were confirmed experimentally (Table 2). $\mathrm{CEA}_{694-702}$ presents low capacity to stabilize cell surface HLA-A*0201 on T2-cells: it presented bad relative affinity scores $(\mathrm{RA}>10)$ and formed short lived complexes with HLA-A2 $(t<1 \mathrm{~h})$.

Analogs of peptide $\mathrm{CEA}_{694-702}$ have higher HLA-A*0201-binding capacities

Because of the low affinity of peptide $\mathrm{CEA}_{694-702}$, we designed three peptide analogs incorporating canonical HLAA*0201 anchor residues (leucine at position 2 and/or valine at position 9). These peptides with sequences GLLVGVALI, GVLVGVALV, and GLLVGVALV will be termed CEA694L2, CEA694V9, and CEA694L2V9, respectively. 

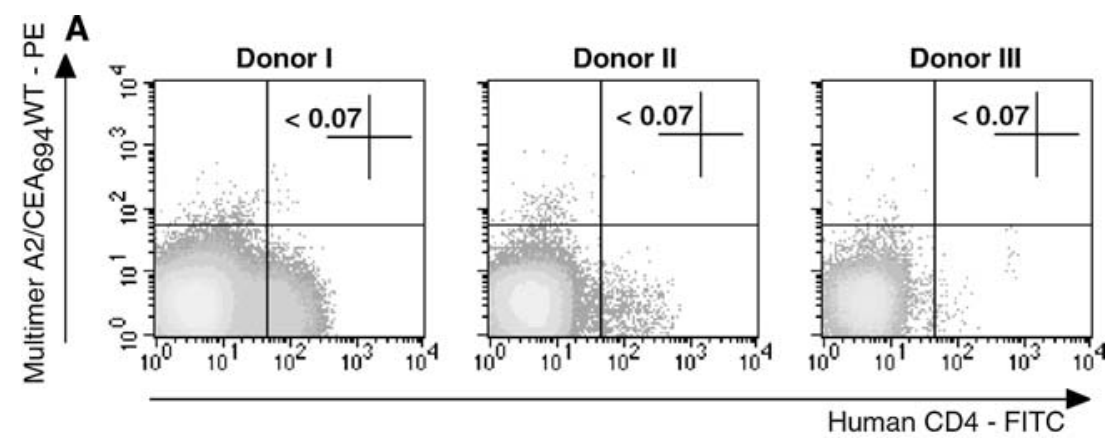

B

Donor IV
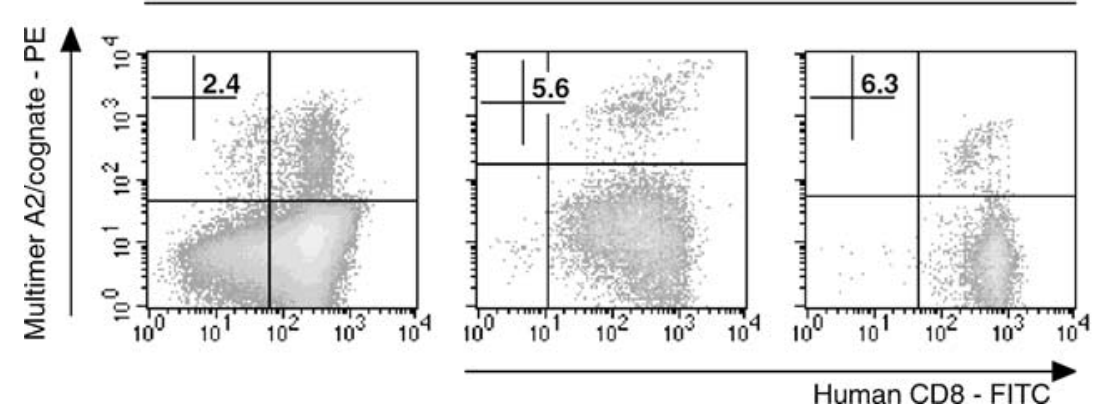

Fig. 1 Immunogenicity of $\mathrm{CEA}_{694-702} \mathrm{WT}$ and analog peptide in HLA-A*0201 healthy donors. a PBMCs from three HLA-A*0201 healthy donors were stimulated first with peptide-pulsed autologous matured dendritic cells and two consecutive times with irradiated T2cells pulsed with peptide $\mathrm{CEA}_{694-702}$ WT. The presence of peptide-specific $\mathrm{CD} 8^{+} \mathrm{T}$-cells was assessed by multiparameter flow cytometry analysis 1 week after the last restimulation on cultured cells labeled

Table 1 Immunogenicity of $\mathrm{CEA}_{694-702}$ and altered peptide ligands

\begin{tabular}{|c|c|c|c|}
\hline Peptide & $\begin{array}{l}\text { In vitro } \\
\text { expansion } \\
\text { method }\end{array}$ & $\begin{array}{l}\text { Number of } \\
\text { significant } \\
\text { expansions }\end{array}$ & $\begin{array}{l}\text { Number } \\
\text { of cultures } \\
\text { tested }\end{array}$ \\
\hline \multirow[t]{2}{*}{$\mathrm{CEA}_{694-702} \mathrm{WT}$} & Microculture $^{\mathrm{a}}$ & 0 & 4 \\
\hline & $\mathrm{DC}_{\text {based }}{ }^{\mathrm{b}}$ & 0 & 5 \\
\hline \multirow[t]{2}{*}{$\mathrm{CEA}_{694-702} \mathrm{~L} 2$} & Microculture & 3 & 4 \\
\hline & DC based & 2 & 5 \\
\hline \multirow[t]{2}{*}{$\mathrm{CEA}_{694-702} \mathrm{~V} 9$} & Microculture & 0 & 4 \\
\hline & DC based & 1 & 5 \\
\hline \multirow[t]{2}{*}{$\mathrm{CEA}_{694-702} \mathrm{~L} 2 \mathrm{~V} 9$} & Microculture & 3 & 4 \\
\hline & DC based & 2 & 5 \\
\hline
\end{tabular}

All experiments were performed by in vitro stimulation of PBMCs from nine HLA-A*0201 positive healthy donors with the indicated peptides

${ }^{\text {a }}$ In vitro stimulation was carried out in multiple parallel PBMC microcultures as described in Materials and methods

${ }^{b}$ In vitro stimulation was carried out by co-culture of purified CD8 ${ }^{+}$ T-cells and autologous peptide-pulsed DCs and peptide-pulsed T2cells at a ratio of $5: 1$

c After 10 days of microculture or three rounds of in vitro stimulation (DC based), cells were labeled with anti-CD8 and A2/CEA peptide multimers. A culture was considered as positive when the number of CD8 A2/CEA peptide multimer cells was higher than $0.1 \%$ of $\mathrm{CD}^{+}$ T-cells

with anti-CD4 mAb and A2/CEA $694-702$ multimers. b Representative results from PBMC of one HLA-A*0201 healthy donor stimulated with peptide $\mathrm{CEA}_{694-702} \mathrm{~L} 2$ (left), $\mathrm{CEA}_{694-702} \mathrm{~V} 9$ (center), and $\mathrm{CEA}_{694-702}$ L2V9 (right) independently. Flow cytometry analysis was performed after three rounds of in vitro stimulation with anti-CD8 mAb and the corresponding A2/cognate peptide multimers

When the canonical HLA-A*0201 anchor motifs were introduced into the peptide sequence, their binding to HLA-A2 improved substantially as reflected by their enhanced ability to stabilize surface HLA-A2 expression in T2-cells (Table 2). Moreover, CEA694L2, CEA694V9, and CEA694L2V9 analog peptides showed relative affinity values 8-24 times higher than the wild-type peptide. The CEA694L2V9 variant presented the highest affinity. Moreover, the CEA694L2V9 and CEA694V9 and to a lesser degree CEA694L2 peptide analogs substantially increased the stability of surface HLA-A2 expression at $37^{\circ} \mathrm{C}$. In summary, $\mathrm{CEA}_{694-702}$ peptide analogs have increased affinity to HLA-A*0201 MHC class-I allele as compared to the wild-type peptide.

$\mathrm{CEA}_{694-702}$ peptide analogs stimulate specific T-cells

A new series of in vitro stimulation with several human HLA-A*0201 healthy donors PBMCs were performed to assess the immunogenicity of the CEA694L2, CEA694V9, and CEA694L2V9 peptide analogs. As depicted in Fig. 1b and summarized in Table 1, the $\mathrm{CEA}_{694-702}$ peptide analogs lead to vigorous expansion of peptide analog-specific $\mathrm{CD} 8^{+}$ $\mathrm{T}$-cells, in clear contrast to the native $\mathrm{CEA}_{694-702}$. In particular, 
Table 2 Predicted and experimental peptide binding to HLA-A*0201

\begin{tabular}{|c|c|c|c|c|c|}
\hline Peptide & BIMAS $^{\mathrm{a}}$ & SYFPEITHI $^{\mathrm{a}}$ & MFI ratio $\Delta(n=5)^{\mathrm{b}}$ & $\mathrm{RA}(n=4)^{\mathrm{c}}$ & Stability DC50 $(\mathrm{h})^{\mathrm{d}}$ \\
\hline GVLVGVALI CEA $694-702$ WT & 8 & 23 & $0.92 \pm 0.37$ & $23.74 \pm 14.12$ & $<1$ \\
\hline GLLVGVALI CEA $_{694-702} \mathrm{~L} 2$ & 89 & 29 & $1.18 \pm 0.39$ & $3.15 \pm 3.82$ & $1-2$ \\
\hline 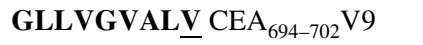 & 52 & 25 & $1.87 \pm 0.39$ & $2.23 \pm 0.89$ & $2-4$ \\
\hline GLLVGVAL $\underline{\text { CEA }}{ }_{694-702} \mathrm{~L} 2 \mathrm{~V} 9$ & 592 & 31 & $1.78 \pm 0.19$ & $0.98 \pm 0.17$ & $4-6$ \\
\hline GVLARVALI CEA ${ }_{694} \mathrm{AR} 4$ & 8 & 21 & n.d. & n.d. & n.d. \\
\hline GVLAGMALI CEA ${ }_{694} \mathrm{AGM}_{4}$ & 8 & 19 & n.d. & n.d. & n.d. \\
\hline GVVALVALI CEA ${ }_{694}$ VAL3 $^{2}$ & 8 & 20 & n.d. & n.d. & n.d. \\
\hline IVGAETFYV HIVpol ${ }_{589-597}$ & 330 & 18 & $3.28 \pm 0.61$ & - & n.d. \\
\hline
\end{tabular}

${ }^{a}$ Each peptide sequence was entered into the BioInformatics and Molecular Analysis Section (BIMAS [26]) or the SYFPEITHI [30] algorithms. The HLA-A2 binding score output is annotated in the corresponding columns

${ }^{b}$ Values are the ratio between anti-HLA-A2 mean fluorescence intensity measured on T2-cells loaded with saturating concentrations of peptide in serum-free media and non-loaded T2-cells

${ }^{c}$ RA-relative HLA-A2 affinity values, which are calculated as described in the Materials and methods section

${ }^{\mathrm{d}}$ Stability DC50 is the number of hours required to attain half maximal anti-HLA-A2 fluorescence at the surface of T2-cells at $37^{\circ} \mathrm{C}$ after removal of peptide from media

CEA694L2 and CEA694L2V9 were the analogs that elicited more frequently detectable responses and independent of the method of in vitro expansion used.

Cloned CD8 ${ }^{+}$T-cells specific for the CEA694L2 analog efficiently cross-recognize the native $\mathrm{CEA}_{694-702}$ peptide

Using multimer-guided cell sorting and limiting dilution techniques, we isolated $\mathrm{CD}^{+} \mathrm{T}$-cell clones specific for each of the $\mathrm{CEA}_{694-702}$ peptide analogs. Only stable $\mathrm{CD}^{+}$ T-cell clones were obtained upon sorting with A2/ CEA694L2 multimers $(n=11)$. Other clones isolated with A2/CEA694, A2/CEA694V9, or A2/CEA694L2V9 multimers were not specific or with very limited proliferative capacity and, therefore, detailed characterization was not possible. Thus, all functional assays were conducted using CTL clones obtained with CEA694L2-specific multimers. We first assessed the level of cross-reactivity between native $\left(\mathrm{CEA}_{694-702}\right)$ and the analog (CEA694L2) peptides by staining the CEA694L2-specific $\mathrm{CD}^{+}{ }^{+} \mathrm{T}$-cell clones with HLA-A2 multimers incorporating either $\mathrm{CEA}_{694-702}$ or CEA694L2 peptides. As shown in Fig. 2a, the clone no. R1, representative of all clones analyzed, is efficiently labeled by the two multimers, albeit the intensity of the fluorescent signal was higher when stained with the A2/CEA694L2 specific multimer. This observation suggests the higher TCR avidity for the peptide analog-MHC complex [45].

We then assessed the level of functional cross-reactivity between the $\mathrm{CEA}_{694-702}$ and CEA694L2 peptides in a chromium release assay. As depicted in Fig. 2b, the representative T-cell clone no. R1 recognized and lysed peptide sensitized HLA-A2 ${ }^{+}$T2-cells efficiently. Half maximal lysis was observed at analog peptide concentrations ranging between 1 and $10 \mathrm{nM}$ for all the clones tested $(n=11)$.
Recognition of the native peptide was equally efficient. We also extended the analysis of CEA antigen cross-reactivity to naturally occurring $\mathrm{CEA}_{694-702}$ peptides present in other CEA family members. These include GVLVGVALV, which in fact is identical to one of the designed peptide analogs described above-CEA694V9 (CEACAM3 and CEACAM4), GVVALVALI (CEACAM1), GVLARVALI (CEACAM6 and CEACAM8), and GVLAGMALI (CEACAM7). As shown in Fig. 2c, only the GVLVGVALV analog was cross-recognized by the CEA694L2 peptidespecific no. R1 T-cell clone, thus suggesting the potential capacity to recognize CEACAM3-, CEACAM4-, and CEACAM5-derived antigens.

These results show that the clone $\mathrm{CEA}_{694-702} \mathrm{~L} 2$ no. $\mathrm{R} 1$ is cross-reactive to native and high HLA-A2 affinity peptide analogs with intermediate to low-functional avidity.

Tumor-cell recognition by CEA-specific CTL clones

We next assessed the ability of peptide analog-specific cloned $\mathrm{CD}^{+}{ }^{+} \mathrm{T}$-cells to recognize CEA-expressing human tumor cell lines. We first evaluated the expression levels of CEACAM3, CEACAM4, and CEACAM5 in the tumor cells by semi-quantitative RT-PCR. As shown in Fig. 3a, CEACAM3 and CEACAM4 were found to be selectively expressed by granulocytes isolated from human PBMC [18, 22]. None of the epithelial cell lines tested detectably expressed those transcripts by semi-quantitative PCR. In contrast, several epithelial tumor cell lines expressed $C E A$ CAM5 mRNA especially SW403, KATOIII, and LOVO. The expression in those cells was higher or equal to $\beta$-actin expression levels. CEACAM5 was undetectable in HCT116 and SW480. Other cell lines such as SW620, COLO201, SW1116, and T84 expressed relatively low 

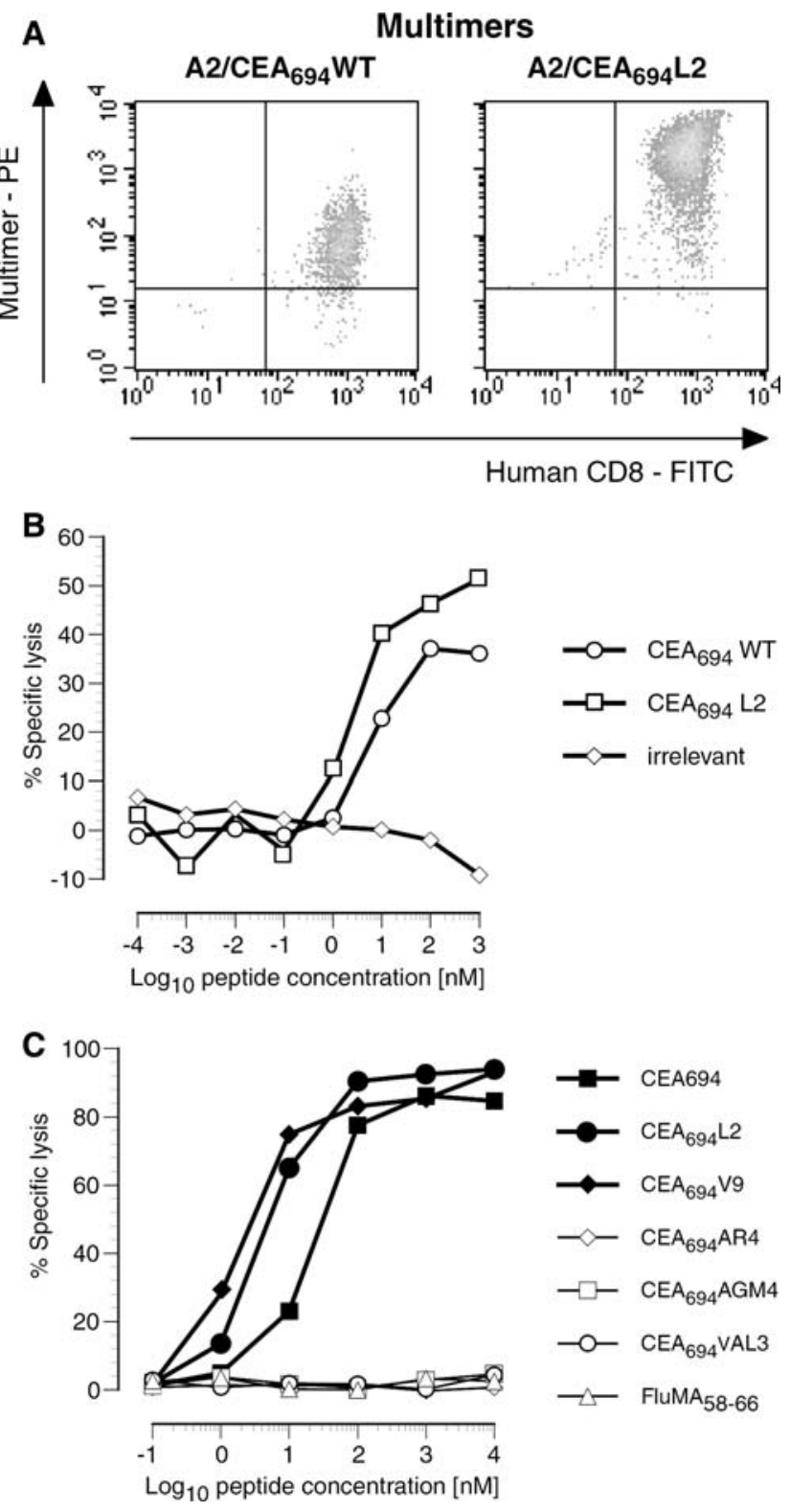

Fig. 2 Fine specificity of CEA analog peptide-specific T-cells. a A2/ $\mathrm{CEA}_{694-702} \mathrm{WT}$ and $\mathrm{A} 2 / \mathrm{CEA}_{694-702} \mathrm{~L} 2$ multimer staining profile of $\mathrm{CEA}_{694-702} \mathrm{~L} 2$ no. R1 CTL clone. b $\mathrm{CEA}_{694-702} \mathrm{WT}$ and $\mathrm{CEA}_{694-702} \mathrm{~L} 2$ peptide recognition efficiency of the same CTL clone. $\mathbf{c}$ Efficiency of recognition of peptide analogs of $\mathrm{CEA}_{694-702}$ derived from CEACAM5 and other family members (CEACAM1- CEA $_{694}$ VAL3, CEACAM3- $\mathrm{CEA}_{694} \mathrm{~V} 9$, CEACAM4- $\mathrm{CEA}_{694} \mathrm{~V} 9$, CEACAM6 $\mathrm{CEA}_{694}$ ARV4, CEACAM7- $\mathrm{CEA}_{694} \mathrm{AGM}_{4}$, and CEACAM8- $\left.\mathrm{CEA}_{694} \mathrm{ARV4}\right)$ by $\mathrm{CEA}_{694-702} \mathrm{~L} 2$ no. R1 CD8+ T-cell clone

levels. Similar results were found when the levels of protein expression were evaluated by flow cytometry with a pan-CEA-specific antibody (data not shown).

We then assessed the ability of no. R1 T CTL clone to recognize and lyse tumor cell lines. As shown in Fig. 3b, the clone was able to recognize and efficiently kill all HLAA*0201 tumor cell lines pulsed with the native $\mathrm{CEA}_{694-702}$

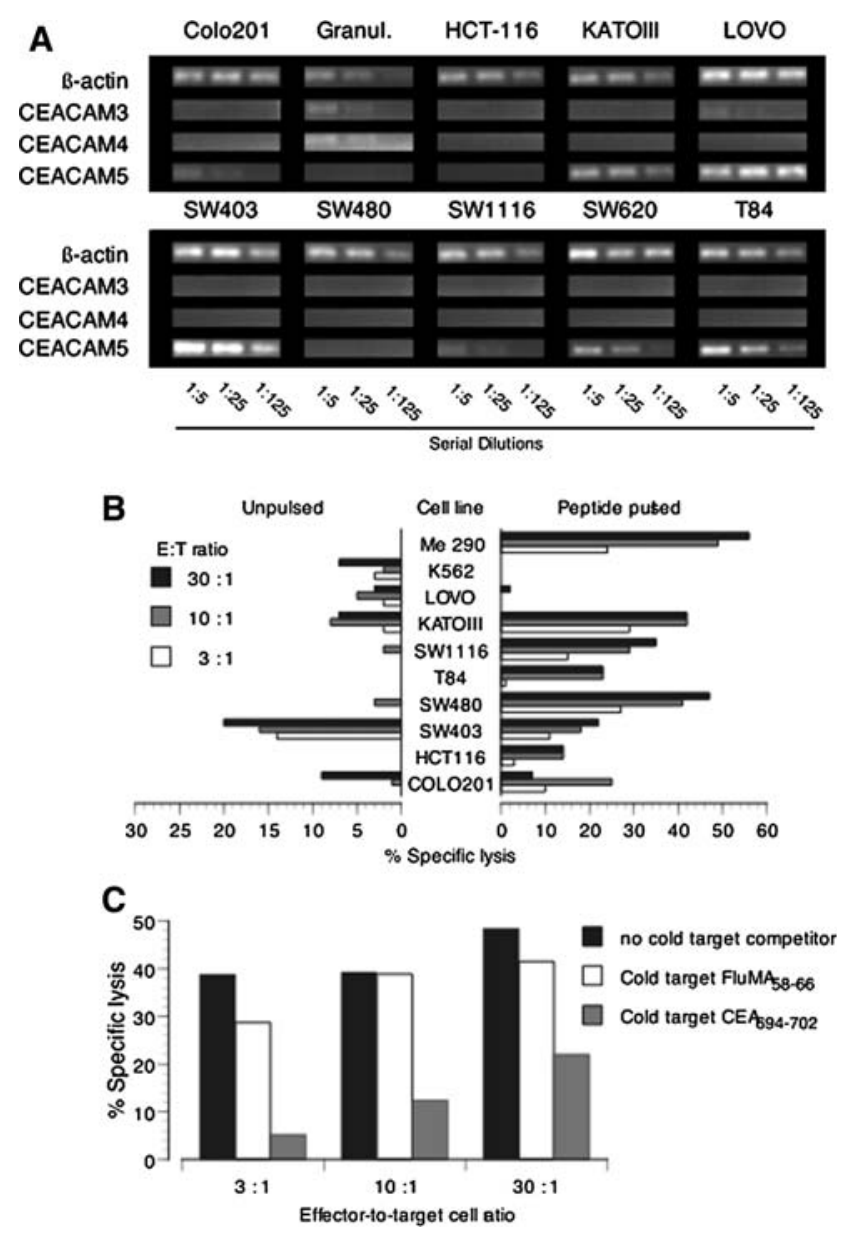

Fig. 3 Naturally processed antigen presentation by CEA positive colorectal carcinoma cell lines. a Semi-quantitative mRNA expression analysis of human tumor cell lines. The transcripts for $\beta$-actin, CEACAM3, CEACAM4, and CEACAM5 were amplified by RT-PCR from serially diluted reverse-transcribed total RNA extracted from cell lines. b Recognition of human tumor cell lines by $\mathrm{CEA}_{694-702} \mathrm{~L} 2$ no. R1 CD8+ T-cell clone in a chromium release assay. Pulsed targets were loaded with $1 \mu \mathrm{g} / \mathrm{ml}_{\text {of }} \mathrm{CEA}_{694-702}$ peptide. $\mathbf{c}$ Peptide-dependent recognition of SW403 colon cancer cell line assessed by cold-target inhibition. The ratio cold : hot was 10:1. Cold targets were T2-cells pulsed with either $1 \mu \mathrm{g} / \mathrm{ml}$ of $\mathrm{CEA}_{694-702}$ peptide or $1 \mu \mathrm{g} / \mathrm{ml}$ of FluMA ${ }_{58-66}$ peptide

peptide. However, in the absence of exogenously added peptide, it only killed the SW403 colon cancer cell line. Close to background lysis levels were observed for KATO III $\left(\mathrm{HLA}^{-\mathrm{A} 2^{+}}\right.$), COLO201 $\left(\mathrm{HLA}^{-\mathrm{A}} 2^{+}\right.$), and SW620 (HLA$\mathrm{A} 2^{+}$). Importantly, SW1116 (HLA-A2 ${ }^{+}$), the cell line from which the peptide $\mathrm{CEA}_{694-702}$ was eluted, was not recognized. A similar deficiency of recognition and lysis was observed with the T84 and SW480 tumor cell lines. As expected, background levels of lysis were present with the cell lines LOVO (HLA-A2 ${ }^{-}$), Me 290 (HLA-A2 melanoma cell line, $\mathrm{CEA}^{-}$), and $\mathrm{K} 562$ (NK sensitive). We further evaluated the specificity of recognition of the SW403 cell line using a cold-target inhibition of cell lysis assay. As 
depicted in Fig. 3c, the recognition of SW403 by the clone CEA694L2 no. R1 was significantly reduced by the presence of excess cold-targets (T2-cells) pulsed with $\mathrm{CEA}_{694-702}$ native peptide. In contrast, cold-targets pulsed with an irrelevant peptide did not inhibit lysis of SW403, thus confirming the peptide specificity of the observed tumor cell lysis. We also tested the recognition of HLA-A $* 0201$ positive granulocytes by both the $\mathrm{T}$-cell clone and polyclonal CEA694L2-specific CTLs in cytolytic assays. However, no evidence of T-cell recognition could be detected even in the presence of exogenously added native $\mathrm{CEA}_{694-702}$ peptide (data not shown).

Overall, these results show that peptide $\mathrm{CEA}_{694-702}$ can be processed and presented by tumor cells lines expressing HLA-A*0201 and high levels of CEACAM5.

\section{Analysis of $\mathrm{CEA}_{694-702}$-specific CD8+ T-cell responses in colon cancer patients}

We next addressed the existence of $\mathrm{CEA}_{694-702}$-specific $\mathrm{CD} 8^{+} \mathrm{T}$-cell responses in a group of HLA-A $2^{+}$colon cancer patients. To assess the possible existence of high frequencies of $\mathrm{CEA}_{694-702}$-specific $\mathrm{CD}^{+} \mathrm{T}$-cells, we labeled PBMCs from three HLA-A*0201 colon cancer patients with A2/CEA ${ }_{694-702} \mathrm{~L} 2$ multimers. As summarized in Table 3, none of the three cancer patients had detectable CEA694L2-specific CD8 ${ }^{+}$T-cells ex vivo. However, after a single stimulation of PBMCs with peptide CEA694L2, CEA694L2-specific CD8 ${ }^{+}$T-cells significantly expanded in two of three patients to numbers as high as $3 \%$ of the total $\mathrm{CD} 8^{+} \mathrm{T}$-cell population. The patient that failed to respond

Table 3 Immunogenicity of $\mathrm{CEA}_{694-702} \mathrm{~L} 2$ peptide in HLA-A*0201 colon cancer patients

\begin{tabular}{|c|c|c|c|c|c|c|}
\hline \multirow[t]{2}{*}{ Peptide } & \multicolumn{3}{|c|}{ Ex vivo $^{a}$} & \multicolumn{3}{|c|}{ In vitro $^{\mathrm{b}}$} \\
\hline & $\begin{array}{l}\text { LAU } \\
89 x^{c}\end{array}$ & $\begin{array}{l}\text { LAU } \\
896^{\mathrm{d}}\end{array}$ & $\begin{array}{l}\text { LAU } \\
919^{\mathrm{e}}\end{array}$ & $\begin{array}{l}\text { LAU } \\
89 ?\end{array}$ & LAU & $\begin{array}{l}\text { LAU } \\
919\end{array}$ \\
\hline Irrelevant & n.d. & n.d. & n.d. & 0.4 & 0.1 & 0.6 \\
\hline FluMA $_{58-66}$ & $<0.07$ & $<0.07$ & n.d. & 0.6 & 6.4 & 76.6 \\
\hline CEA694L2 & $<0.07$ & $<0.07$ & $<0.07$ & 0.2 & 3.2 & 2.4 \\
\hline
\end{tabular}

n.d. not done

${ }^{\text {a }}$ Ex vivo flow cytometry analysis of $\mathrm{CD}^{+}$A2/CEA694L2 multimer $^{+}$T-cells in PBMC analysis

b PBMCs from HLA-A*0201 colon cancer patients were stimulated with peptide $\mathrm{CEA}_{694-702} \mathrm{~L} 2$ at $10 \mu \mathrm{g} / \mathrm{ml}$. rIL-2 at $1,000 \mathrm{IU} / \mathrm{ml}$ was added $48 \mathrm{~h}$ after stimulation and every other day after that. Anti-CD8 and A2/CEA694L2 multimer analyses were performed at day 10. The figures represent the percentage of $\mathrm{CD}^{+} \mathrm{CD}^{+}$multimer $^{+}$events

c 57 years old, TMN: pT4 pN1 Mx

d 56 years old, TMN: pT4 pN2 pMx

e 57 years old, TMN pT4 pN2 pMx to the stimulation protocol also showed no detectable expansion of FluMA ${ }_{58-66}$ peptide-specific $\mathrm{CD}^{+}{ }^{+} \mathrm{T}$-cells, suggesting low responsiveness of the T-cells. PBMCs stimulated with the immunogenic HLA-A*0201-restricted peptide NY-ESO-1 $1_{157-165}$ did not generate CEA694L2-specific $\mathrm{CD} 8^{+} \mathrm{T}$-cells, demonstrating the antigen specificity of the induced T-cells (Fig. 4a).

These results reveal the presence of $\mathrm{CEA}_{694-702}$-specific $\mathrm{T}$-cells in the peripheral blood of cancer patients that can be mobilized and expanded using peptide analogs of higher HLA-A*0201 affinity.

We further extended the study of these in vitro responses by CEA694L2 multimer-specific guided cell sorting and establishment of $\mathrm{CD}^{+} \mathrm{T}$-cell clones by limiting dilution. These clones were then characterized for their cross-recognition of the native peptide. As shown in Fig. 4b, a surprisingly low efficiency of antigen recognition was recorded for the great majority of the T-cell clones evaluated in native peptide titration assays. They attained half maximal lysis with concentrations of native $\mathrm{CEA}_{694-702}$ peptide that were approximately one $\log$ higher than those required by CTL clones isolated from PBMC of healthy donors (Fig. 2b). At the same time, these series of T-cell clones obtained from cancer patients displayed a marked high level of recognition efficiency of the CEA694L2 analog peptide. The reduced cross-recognition activity of these CTL clones and their lower lytic efficiency forecasted a reduced or complete abrogation of tumor-cell recognition. Cytolytic assays were performed with multimer-sorted bulk T-cell populations and several T-cell clones of different avidities (Fig. 4c). The results obtained confirmed our expectations on the potential failure of the CTL clones generated from cancer patients, as these CTL were unable to recognize tumor cells expressing CEA antigen even when treated with IFN- $\gamma$ for $72 \mathrm{~h}$, a treatment commonly used to increase HLA class-I expression [35].

\section{Discussion}

We have addressed the potential immunogenicity of a CEA-derived non-apeptide identified 6 years ago as an HLA-A2 binding peptide [33]. The promise of this peptide as a bona fide tumor-associated antigen stemmed from the evidence that the peptide is naturally processed. Indeed, the peptide was found via the biochemical analysis of the pool of peptides eluted from MHC class-I molecules that had been purified from an HLA-A2 ${ }^{+}$colorectal carcinoma cell line. Our experimental analysis lead to the following conclusions: (1) the native peptide binds weakly to the HLA-A2 molecule and is poorly immunogenic in an in vitro culture system, (2) introduction of the two major anchors for HLA-A2 substantially improves both binding 
A

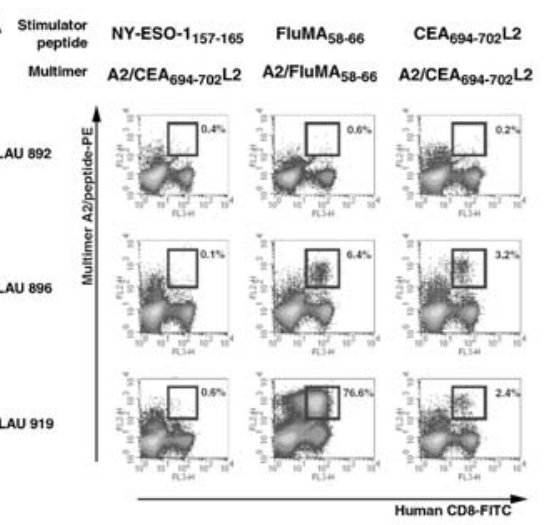

B

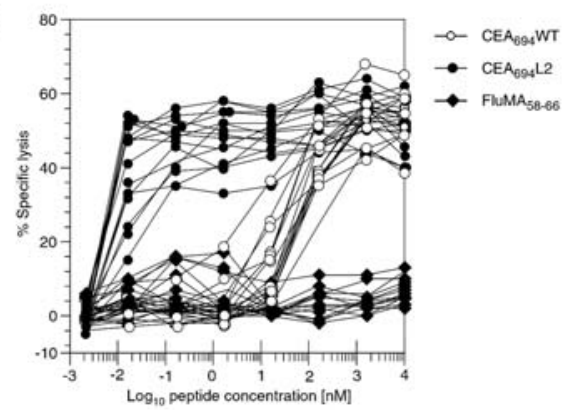

C

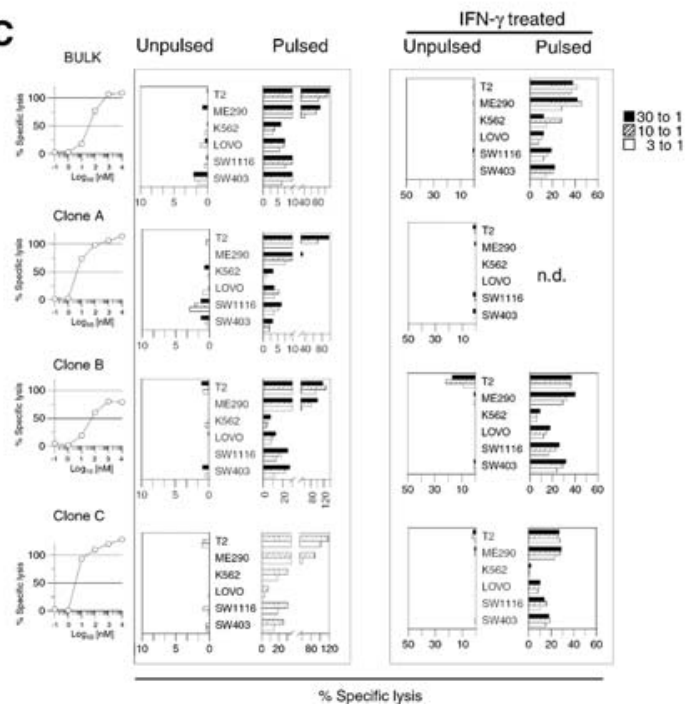

Fig. 4 Immunogenicity of the $\mathrm{CEA}_{694-702} \mathrm{~L} 2$ peptide analog in HLAA*0201 colon cancer patients and tumor reactivity of CD8+ T-cell clones. a PBMCs from three HLA-A2 colon cancer patients were stimulated with $10 \mu \mathrm{g} / \mathrm{ml}$ of peptide and cultured for 10 days in $1,000 \mathrm{IU} / \mathrm{ml}$ IL-2. FluMA ${ }_{58-66}$ and NY-ESO- $1_{157-165}$ peptides were used as controls of peptide-specific CTL induction. Cells were labeled with the indicated A2 multimer and anti-CD8 mAb. Data is summarized in Table 3. b CEA ${ }_{694-702} \mathrm{WT}_{\text {and }} \mathrm{CEA}_{694-702} \mathrm{~L}_{2}$ peptide recognition efficiency of the 18 patient-derived CTL clones generated from A2/CEA ${ }_{694-702}$ multimers-guided cell sorting and limiting dilution. c Tumor-cell recognition of tumor cell lines expressing CEA antigen. Left panel shows CD8+ T-cell functional avidity of polyclonal and clonal populations. Center panel presents histograms of tumor recognition in chromium release assay unpulsed or pulsed with CEA $_{694-702}$ peptide. Right panel shows CTL recognition of tumor cells unpulsed or pulsed with $\mathrm{CEA}_{694-702}$ peptide but pre-treated for $72 \mathrm{~h}$ with IFN- $\gamma$ to HLA-A2 and in vitro immunogenicity, (3) peptide analog-specific CTL clones generated from healthy donor lymphocytes can be tumor reactive and display intermediate functional TCR avidity, and (4) peptide analog-specific CTL generated from colorectal carcinoma patients have a significantly lower TCR avidity for cross-recognition of the native $\mathrm{CEA}_{694-702}$ peptide and fail to recognize tumor cells expressing both HLA-A2 and CEA.

In contrast to the so-called direct immunology approach to identify CTL-defined tumor antigens [14, 42], where tumor cell lysis by CTLs already proves that naturally processed antigen is recognized and can trigger CTLs, both reverse immunology [43] and biochemical methods for identification of T-cell epitopes [29, 33] require proof that the hypothetical antigenic candidates are naturally processed and immunogenic. In this regard, for several tumor antigen candidates, contradictory data have been reported concerning peptide immunogenicity, presentation by tumor cells, and tumor cell peptide-specific CTL tumor recognition $[2,4,7,19,27,31,32,41,44]$. Therefore, it is critical for the appropriate validation of tumor-derived CD8+ Tcell epitopes that reproducible data on the antigen processing, immunogenicity, functional performance of induced CTLs, and tumor cell recognition are provided.

From the list of eluted peptides, reported by Shirle et al., the previously unknown peptide $\mathrm{CEA}_{694-702}$ was described [33]. Surprisingly, other previously known CEA HLA-A*0201 $\mathrm{CD}^{+}$peptides were not detected, raising doubts concerning the efficiency of their antigen processing. However, peptides may be present at too low numbers, or other reasons may account for lack of peptide identification by biochemical analysis of material obtained with acid elution.

Our findings pose a paradox: that a peptide with low affinity for HLA-A*0201 and forming unstable complexes could be successfully identified from the mixture of MHC class-I eluted peptides, in both a tumor cell line and a tumor tissue fragment [33]. Nevertheless, successful identification of naturally processed peptides with low affinity to HLAA2 molecules has been reported [36]. It is conceivable that the original eluted fraction from which the peptide was identified was composed of a mix of closely related peptide analogs, which provided fragment signals leading to the $\mathrm{CEA}_{694-702}$ sequence prediction. However, screening for HLA-A*0201-binding natural CEA ${ }_{694-702}$ analogs in human protein databases consistently provided CEA family-related protein-derived peptides (CEACAM1 $1_{436-444}$ : GVVALVALI, CEACAM3 $_{159-167}$ : GVLGVGALV, CEACAM4 ${ }_{159-167}$ :

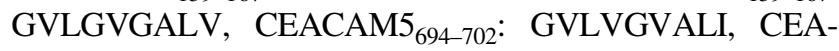

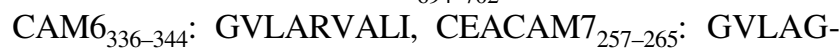
MALI, and CEACAM8 ${ }_{341-349}$ : GVLARVALI). Among these, only the GVLVGVALI and GVLVGVALV peptides were cross-recognized by the CEA694L2 no. R1 clone 
(Fig. 2c). Other variants were not detectably cross-recognized and are predicted as very weak binders to HLAA*0201 (Table 2).

Furthermore, the semi-quantitative PCR analysis suggests that CEACAM5 is the likely source of the peptide present in the peptide elution pool, as all colon epithelial tumor cells, including the SW1116 cell line, expressed detectable amounts of the CEACAM5 cDNA. Moreover, CEACAM3 and CEACAM4, which code for cross-recognized peptides with GVLVGVALI, are not expressed by tumor cell lines (Fig. 3a). Alternatively, it can be hypothesized that the off-rate of the low-affinity peptide CEA694 is compensated by a high rate of antigen synthesis, proteolysis, and derived peptide presentation at the cell surface [28, 46]. It is interesting to note that the CEA694-702 epitope is located at the carboxyl terminus of CEACAM5, which ensures its release in the cytoplasm by proteasomal degradation [11].

The expression of CEACAM5 in epithelial tissues may likely result in the induction of both central and peripheral tolerance [17], as has been previously described for other tumor-associated antigens, e.g., p53, gp100 [15, 24]. Our findings are in agreement with the hypothesis that tolerance to CEA antigen may exist in humans. First, the immunogenic CEA peptide analogs display differential CTL induction efficiency, as their relative immunogenicity does not strictly correlate with their relative HLA-A*0201-binding capacity. Second, the peptide-specific $\mathrm{CD}^{+} \mathrm{T}$-cell clones all had low to intermediate TCR avidities irrespective of whether they had been induced by CEA694L2, CEA694V9, or CEA694L2V9. In addition, clones derived by stimulation with the CEA694V9 and CEA694L2V9 had a very limited proliferation capacity. Moreover, other independent studies with different CEACAM5-derived peptides have also reported low to intermediate TCR avidities [47]. Third, $\mathrm{CD}^{+} \mathrm{T}$-cell clones generated from colon cancer patients had in general lower avidity toward the $\mathrm{CEA}_{694-702}$ peptide than $\mathrm{CD} 8+\mathrm{T}$-cell clones generated from human healthy donors and were unable to recognize CEACAM5 expressing tumor cells even when treated with IFN- $\gamma$. These results suggest that tumor-derived CEA may drive in parallel both the expansion of $\mathrm{CEA}_{694-702}$-specific CD8+ T-cells in vivo and the deletion of T-cells with relatively high-TCR avidity. The fact that these patients often present high levels of CEA antigen in their serum might contribute to these processes.

Altogether, the present findings raise serious concerns on the efficacy of immunological tumor surveillance provided by the $\mathrm{CEA}_{694-702}$-specific $\mathrm{CD}^{+} \mathrm{T}$-cells; particularly because the native epitope is poorly immunogenic, the specific $\mathrm{T}$-cell repertoire induced by peptide analogs shows low avidity in colon cancer patients and fails to recognize allogenic tumor cells expressing CEACAM5.
Acknowledgments This study was supported in part by Swiss National Science Foundation special program NCCR Molecular Oncology. We would like to acknowledge the technical support of Estelle Devevre and Frederic Grosjean and Nicole Montandon.

\section{References}

1. Altman JD, Moss PA, Goulder PJ, Barouch DH, McHeyzerWilliams MG, Bell JI, McMichael AJ, Davis MM (1996) Phenotypic analysis of antigen-specific T lymphocytes. Science 274:94-96

2. Alves PM, Faure O, Graff-Dubois S, Cornet S, Bolonakis I, Gross DA, Miconnet I, Chouaib S, Fizazi K, Soria JC, Lemonnier FA, Kosmatopoulos K (2006) Steap, a prostate tumor antigen, is a target of human CD8(+) T cells. Cancer Immunol Immunother 55:1504-1514

3. Alves PM, Faure O, Graff-Dubois S, Gross DA, Cornet S, Chouaib S, Miconnet I, Lemonnier FA, Kosmatopoulos K (2003) Epha2 as target of anticancer immunotherapy: identification of HLAA*0201-restricted epitopes. Cancer Res 63:8476-8480

4. Ayyoub M, Migliaccio M, Guillaume P, Lienard D, Cerottini JC, Romero P, Levy F, Speiser DE, Valmori D (2001) Lack of tumor recognition by Htert peptide $540-548$-specific CD8(+) T cells from melanoma patients reveals inefficient antigen processing. Eur J Immunol 31:2642-2651

5. Berinstein NL (2002) Carcinoembryonic antigen as a target for therapeutic anticancer vaccines: a review. J Clin Oncol 20:21972207

6. Dalerba P, Maccalli C, Casati C, Castelli C, Parmiani G (2003) Immunology and immunotherapy of colorectal cancer. Crit Rev Oncol Hematol 46:33-57

7. Dupont J, Latouche JB, Ma C, Sadelain M (2005) Artificial antigen-presenting cells transduced with telomerase efficiently expand epitope-specific, human leukocyte antigen-restricted cytotoxic T cells. Cancer Res 65:5417-5427

8. Eidelman FJ, Fuks A, DeMarte L, Taheri M, Stanners CP (1993) Human carcinoembryonic antigen, an intercellular adhesion molecule, blocks fusion and differentiation of rat myoblasts. J Cell Biol 123:467-475

9. Faure O, Graff-Dubois S, Bretaudeau L, Derre L, Gross DA, Alves PM, Cornet S, Duffour MT, Chouaib S, Miconnet I, Gregoire M, Jotereau F, Lemonnier FA, Abastado JP, Kosmatopoulos K (2004) Inducible Hsp70 as target of anticancer immunotherapy: identification of HLA-A*0201-restricted epitopes. Int J Cancer 108:863-870

10. Fong L, Hou Y, Rivas A, Benike C, Yuen A, Fisher GA, Davis MM, Engleman EG (2001) Altered peptide ligand vaccination with Flt3 ligand expanded dendritic cells for tumor immunotherapy. Proc Natl Acad Sci USA 98:8809-8814

11. Goldberg AL, Cascio P, Saric T, Rock KL (2002) The importance of the proteasome and subsequent proteolytic steps in the generation of antigenic peptides. Mol Immunol 39:147-164

12. Graham RA, Wang S, Catalano PJ, Haller DG (1998) Postsurgical surveillance of colon cancer: preliminary cost analysis of physician examination, carcinoembryonic antigen testing, chest X-ray, and colonoscopy. Ann Surg 228:59-63

13. Hammarstrom S (1999) The carcinoembryonic antigen (Cea) family: structures, suggested functions and expression in normal and malignant tissues. Semin Cancer Biol 9:67-81

14. Herin M, Lemoine C, Weynants P, Vessiere F, Van Pel A, Knuth A, Devos R, Boon T (1987) Production of stable cytolytic T-cell clones directed against autologous human melanoma. Int J Cancer 39:390-396

15. Hernandez J, Lee PP, Davis MM, Sherman LA (2000) The use of HLA A2.1/P53 peptide tetramers to visualize the impact of self tolerance on the Tcr repertoire. J Immunol 164:596-602 
16. Jessup JM, Petrick AT, Toth CA, Ford R, Meterissian S, O'Hara CJ, Steele GJ, Thomas P (1993) Carcinoembryonic antigen: eanhancement of liver colonisation through retention of human colorectal carcinoma cells. Br J Cancer 67:464-470

17. Kreuwel HT, Sherman LA (2001) The T-cell repertoire available for recognition of self-antigens. Curr Opin Immunol 13:639-643

18. Kuroki M, Arakawa F, Matsuo Y, Oikawa S, Misumi Y, Nakazato H, Matsuoka Y (1991) Molecular cloning of nonspecific crossreacting antigens in human granulocytes. J Biol Chem 266:1181011817

19. Machlenkin A, Paz A, Bar Haim E, Goldberger O, Finkel E, Tirosh B, Volovitz I, Vadai E, Lugassy G, Cytron S, Lemonnier F, Tzehoval E, Eisenbach L (2005) Human Ctl epitopes prostatic acid phosphatase- 3 and six-transmembrane epithelial antigen of prostate- 3 as candidates for prostate cancer immunotherapy. Cancer Res 65:6435-6442

20. Marshall J (2003) Carcinoembryonic antigen-based vaccines. Semin Oncol 30:30-36

21. Montes M, Rufer N, Appay V, Reynard S, Pittet MJ, Speiser DE, Guillaume P, Cerottini JC, Romero P, Leyvraz S (2005) Optimum in vitro expansion of human antigen-specific CD8 $\mathrm{T}$ cells for adoptive transfer therapy. Clin Exp Immunol 142:292-302

22. Nagel G, Grunert F, Kuijpers TW, Watt SM, Thompson J, Zimmermann W (1993) Genomic organization, splice variants and expression of Cgm1, a CD66-related member of the carcinoembryonic antigen gene family. Eur J Biochem 214:27-35

23. Nap M, Mollgard K, Burtin P, Fleuren GJ (1988) Immunohistochemistry of carcino-embryonic antigen in the embryo, fetus and adult. Tumour Biol 9:145-153

24. Overwijk WW, Tsung A, Irvine KR, Parkhurst MR, Goletz TJ, Tsung K, Carroll MW, Liu C, Moss B, Rosenberg SA, Restifo NP (1998) Gp100/Pmel 17 is a murine tumor rejection antigen: induction of "self"-reactive, tumoricidal T cells using high-affinity, altered peptide ligand. J Exp Med 188:277-286

25. Parham P, Brodsky FM (1981) Partial purification and some properties of Bb7.2. A cytotoxic monoclonal antibody with specificity for HLA-A2 and a variant of HLA-A28. Hum Immunol 3:277-299

26. Parker KC, Bednarek MA, Coligan JE (1994) Scheme for ranking potential HLA-A2 binding peptides based on independent binding of individual peptide side-chains. J Immunol 152:163-175

27. Parkhurst MR, Riley JP, Igarashi T, Li Y, Robbins PF, Rosenberg SA (2004) Immunization of patients with the Htert:540-548 peptide induces peptide-reactive $\mathrm{T}$ lymphocytes that do not recognize tumors endogenously expressing telomerase. Clin Cancer Res 10:4688-4698

28. Princiotta MF, Finzi D, Qian SB, Gibbs J, Schuchmann S, Buttgereit F, Bennink JR, Yewdell JW (2003) Quantitating protein synthesis, degradation, and endogenous antigen processing. Immunity 18:343-354

29. Ramakrishna V, Ross MM, Petersson M, Gatlin CC, Lyons CE, Miller CL, Myers HE, McDaniel M, Karns LR, Kiessling R, Parmiani G, Flyer DC (2003) Naturally occurring peptides associated with HLA-A2 in ovarian cancer cell lines identified by mass spectrometry are targets of HLA-A2-restricted cytotoxic T cells. Int Immunol 15:751-763

30. Rammensee H, Bachmann J, Emmerich NP, Bachor OA, Stevanovic S (1999) SYFPEITHI: database for MHC ligands and peptide motifs. Immunogenetics 50:213-219

31. Rodeberg DA, Nuss RA, Elsawa SF, Celis E (2005) Recognition of six-transmembrane epithelial antigen of the prostate-expressing tumor cells by peptide antigen-induced cytotoxic $\mathrm{T}$ lymphocytes. Clin Cancer Res 11:4545-4552

32. Scardino A, Gross DA, Alves P, Schultze JL, Graff-Dubois S, Faure O, Tourdot S, Chouaib S, Nadler LM, Lemonnier FA,
Vonderheide RH, Cardoso AA, Kosmatopoulos K (2002) Her-2/ Neu and HTERT cryptic epitopes as novel targets for broad spectrum tumor immunotherapy. J Immunol 168:5900-5906

33. Schirle MKW, Weber B, Gouttefangeas C, Dumrese T, Becker HD, Stevanovic S, Rammensee HG (2000) Identification of tumor-associated MHC class I ligands by a novel T cell-independent approach. Eur J Immunol 30:2216-2225

34. Screaton RA, Penn LZ, Stanners CP (1997) Carcinoembryonic antigen, a human tumor marker, cooperates with Myc and Bcl-2 in cellular transformation. J Cell Biol 137:939-952

35. Shaw AR, Chan JK, Reid S, Seehafer J (1985) Hla-Dr synthesis induction and expression in HLA-Dr-negative carcinoma cell lines of diverse origins by interferon-gamma but not by interferon-beta. J Natl Cancer Inst 74:1261-1268

36. Skipper JC, Gulden PH, Hendrickson RC, Harthun N, Caldwell JA, Shabanowitz J, Engelhard VH, Hunt DF, Slingluff CLJ (1999) Mass-spectrometric evaluation of HLA-A*0201-associated peptides identifies dominant naturally processed forms of $\mathrm{Ctl}$ epitopes from Mart-1 and Gp100. Int J Cancer 82:669-677

37. Speiser DE, Pittet MJ, Guillaume P, Lubenow N, Hoffman E, Cerottini JC, Romero P (2004) Ex vivo analysis of human antigenspecific CD8(+) T-cell responses: quality assessment of fluorescent HLA-A2 multimer and interferon-gamma elispot assays for patient immune monitoring. J Immunother 27:298-308

38. Thompson JA, Grunert F, Zimmermann W (1991) Carcinoembryonic antigen gene family: molecular biology and clinical perspectives. J Clin Lab Anal 5:344-366

39. Tourdot S, Scardino A, Saloustrou E, Gross DA, Pascolo S, Cordopatis P, Lemonnier FA, Kosmatopoulos K (2000) A general strategy to enhance immunogenicity of low-affinity HLA-A2. 1-associated peptides: implication in the identification of cryptic tumor epitopes. Eur J Immunol 30:3411-3421

40. Valmori D, Fonteneau JF, Lizana CM, Gervois N, Lienard D, Rimoldi D, Jongeneel V, Jotereau F, Cerottini JC, Romero P (1998) Enhanced generation of specific tumor-reactive CTL in vitro by selected Melan-A/Mart-1 immunodominant peptide analogues. J Immunol 160:1750-1758

41. Valmori D, Gileadi U, Servis C, Dunbar PR, Cerottini JC, Romero P, Cerundolo V, Levy F (1999) Modulation of proteasomal activity required for the generation of a cytotoxic $\mathrm{T}$ lymphocyte-defined peptide derived from the tumor antigen Mage-3. J Exp Med 189:895-906

42. Van den Eynde B, Hainaut P, Herin M, Knuth A, Lemoine C, Weynants P, van der Bruggen P, Fauchet R, Boon T (1989) Presence on a human melanoma of multiple antigens recognized by autologous CTL. Int J Cancer 44:634-640

43. Van Der Bruggen $P$, Zhang Y, Chaux P, Stroobant V, Panichelli C, Schultz ES, Chapiro J, Van Den Eynde BJ, Brasseur F, Boon T (2002) Tumor-specific shared antigenic peptides recognized by human T cells. Immunol Rev 188:51-64

44. Vonderheide RH, Hahn WC, Schultze JL, Nadler LM (1999) The telomerase catalytic subunit is a widely expressed tumor-associated antigen recognized by cytotoxic T lymphocytes. Immunity 10:673-679

45. Yee C, Savage PA, Lee PP, Davis MM, Greenberg PD (1999) Isolation of high avidity melanoma-reactive $\mathrm{Ctl}$ from heterogeneous populations using peptide-Mhc tetramers. J Immunol 162:22272234

46. Yewdell JW (2001) Not such a dismal science: the economics of protein synthesis, folding, degradation and antigen processing. Trends Cell Biol 11:294-297

47. Zhu MZ, Marshall J, Cole D, Schlom J, Tsang KY (2000) Specific cytolytic T-cell responses to human Cea from patients immunized with recombinant Avipox-Cea vaccine. Clin Cancer Res 6:24-33 